\title{
Disability and poverty in Sri Lanka: a household level analysis
}

\author{
P. H. T. Kumara ${ }^{1 *}$ and D. N. B. Gunewardena ${ }^{2}$ \\ ${ }^{I}$ Department of Public Administration, Faculty of Management, Uva Wellassa University, Badulla, Sri lanka. \\ ${ }^{2}$ Department of Economics and Statistics, Faculty of Arts, University of Peradeniya, Peradeniya, Sri Lanka.
}

\begin{abstract}
Sri Lanka has recorded a significant reduction in poverty in recent times. Yet, as in many other developing countries, little or nothing is known about poverty levels and reduction of poverty among the disabled or their households. The disabled and their families encounter different hardships than the typical deprivations of the poor. The recent literature questions the ability of the monetary approach in measuring poverty in general and especially among different groups like the disabled. Therefore, this study estimates both monetary and multidimensional poverty among the households with disabled persons, using the Household Income and Expenditure Survey data of 2006/07 and 2009/10. The study found that monetary and multidimensional poverty among households with disabled persons is higher than among other households. Even though multidimensional poverty is relatively low in Sri Lanka, the difference in multidimensional poverty levels between households with and without the disabled is high. Importantly, contributions from the three dimensions considered in this research to the incidence of poverty is almost equal, suggesting that further reduction of poverty in Sri Lanka requires improvements in all three dimensions - health, education and living standards- among poor households, with and without disabled persons.
\end{abstract}

Keywords: Poverty, disability, multidimensional poverty, Alkire-Foster method, Sri Lanka.

\section{INTRODUCTION}

Although around 15 per cent of world population lives with some form of disability (WHO and World Bank, 2011), the literature on the socioeconomic status of these people are limited, especially in developing countries (Mitra et al., 2013). Sri Lanka is not an exception. Sri Lanka recorded a significant reduction in poverty during the last decade (Department of Census and Statistics, 2011; 2008; 2003) but, as in many other developing countries, less is known about the poverty levels and progress of reduction of poverty among disabled persons and/or their households. This is mainly due to the limitation of reliable data and the poor attention that they receive due to the limited voice of this group (Yeo and Moore, 2003). Disability onset could be due to natural causes such as from birth or later caused by diseases and human activities such as accidents or war. The latter cause an increase in the number of disabled persons in Sri Lanka due to the 30 years of war (Government of Sri Lanka, 2003) and the incidence of disabled persons is increasing (De Silva et al., 2008). Furthermore, Mitra et al. (2013) conclude that the relationship between poverty and disability is significantly strong for the middle income countries. As Sri Lanka expects to move to an upper middle income country soon (Central Bank of Sri Lanka, 2013), it is important to examine the relationship between poverty and disability in Sri Lanka. Hence, this study aims at answering the question whether households with disabled persons achieve a lower levels of wellbeing compared to households with no disabled persons.

Sri Lanka recorded about a five per cent annual average GDP growth rate during the last two decades. The services and industrial sectors contributed to the growth, while contribution from the agricultural sector was minimal and stagnant. Moreover, the agricultural sector's share of GDP declined significantly while dominance of the services sector strengthened. Nevertheless, the economic growth was uneven across different regions. Western Province produced more than 50 per cent of the total GDP while some other Provinces remained at less than five per cent. A higher level of human development ${ }^{1}$ was achieved, but there were wide regional disparities (World Bank, 2007; Kumara and Gunewardena, 2010).

From the perspective of monetary poverty, the unevenness of growth has also brought disappointing results in terms of poverty reduction. Although there was a decline in poverty between $1990 / 91$ and 2006/07 in both urban and rural areas, the estate areas experienced 
an increase in poverty. Moreover, poverty levels of the poorest provinces i.e. Uva and Sabaragamuwa (and the districts they include) exceeded the poverty levels of 1990/91. However, a significant rate of reduction of poverty can be observed with the latest survey data in the national and regional levels. This reduction of national poverty can be attributed mostly to the higher reduction of poverty in rural and estate areas.

Though Sri Lanka recorded a higher rate of reduction of poverty in recent times, poverty among some groups is still higher than the national and regional averages. The reduction of monetary poverty in estate areas is not promising as in other areas. Furthermore, poverty among agricultural workers, women headed households, and marginalised groups are significantly higher than national poverty levels (World Bank, 2007).

Another neglected area is poverty among households with disabled persons. Table 1 shows that there were more than 300,000 disabled persons in Sri Lanka with some kind of disability in 2001 (See Appendix: Figure I for distribution of type of disabilities in Sri Lanka). The literature suggests that poverty in households with disabled persons is higher than that in households without disabled persons (Mitra et al., 2013; Mont \& Viet Cuong, 2011; Filmer 2008; Hoogeveen, 2005). However, this aspect of poverty in Sri Lanka is hardly examined and there is a lack of research on this topic mainly due to unavailability of reliable data.

Physical or mental impairment of disabled persons may limit their school attendance. This in turn will generate lower level of education and consequently create lower level of earning opportunities. Furthermore, person may be able to buy a bicycle, but he or she may not be able to ride it, which eventually lead to lower levels of welfare (the situation can be further aggravated due to unavailability of accessible infrastructure for the disabled persons). Therefore, measuring poverty among these households using only the monetary approach may not reveal the actual situation. Hence, this study estimate poverty among households with disabled persons using both monetary and multidimensional poverty approaches.

The authors accept the fact that reliable data on the socioeconomic status of disabled persons such as their income or expenditure are limited in Sri Lanka. Nevertheless, Household Income and Expenditure Survey (HIES) provides some data on disabled persons in Sri Lanka that can be used in analysing poverty among the disabled. But HIES reports income and expenditure data at household level, hence this study uses the household (where there is a disabled person or persons) as the unit of analysis. Therefore, estimated poverty levels are for the households with disabled persons and not for the individuals with disabilities.

\section{POVERTY: A CAUSE OR AN EFFECT OF DISABILITY?}

The relationship between disability and poverty is complicated due to the reverse causality between disability and poverty. Disability cannot be defined as necessarily a cause of poverty or a consequence of poverty. Therefore, the relationship between disability and poverty can be interpreted as an association only (Filmer, 2008).

Table 1: Disabled persons in Sri Lanka by type of disability

\begin{tabular}{lrrrrrrr}
\hline \multirow{2}{*}{ Sex } & \multicolumn{6}{c}{ Disability in } & \multirow{2}{*}{ Total } \\
\cline { 2 - 7 } & Seeing & Hearing & Hands & Legs & Other Phy. & Mental & \\
\hline Male & 35,419 & 40,584 & 31,070 & 56,529 & 7,344 & 37,181 & 208,127 \\
Female & 33,677 & 32,759 & 17,061 & 34,047 & 5,931 & 3,184 & 126,659 \\
Both Sexes & 69,096 & 73,343 & 48,131 & 90,576 & 13,275 & 40,365 & 334,786 \\
\hline
\end{tabular}

Source: Department of Census and Statistics (2001).

Note: this numbers does not include the disabled persons in war-affected North and Eastern provinces due to data unavailability.

they may have less access to public services and to infrastructure facilities and they may face social stigma due to disability (Mitra et al., 2013). All these may have led to higher levels of poverty among these households. Even though these households achieve a certain level of monetary income, they may face difficulties in translating this monetary value into welfare, for instance a disabled
Disability can lead to poverty as disability reduces the earning ability of households (Mitra et al., 2013; Meyer and Mok, 2008; Gertler and Gruber, 2002; Haveman and Wolfe, 2000; Schultz and Tansel, 1997), generating lower level of living standards. Furthermore, disability can adversely affect the education of the disabled persons as well as the other family members. School 
attendance of disabled persons can be adversely affected by the disability status and the facilities available. Lower levels of school attendance can generate lower levels of human capital accumulation which eventually generates less employment opportunities, less productivity and lower earnings (Mitra et al., 2013). Moreover, disability can increase the level of household expenditure on education due to additional cost involved with disability, such as transportation, health care, assistive services and personal care (Mitra et al., 2013; Braithwaite and Mont, 2009; Mitra et al., 2009; Zaidi and Burchardt, 2005; Jones and O'Donnell, 1995). A disabled person may need more expenditure to achieve the same amount of welfare depending on the disability status. For example, a person with no visibility may need the assistance of someone else (a service dog in a developed county) to move around. This may increase the amount of money and time that he or she needs to spend for moving from one place to another compared to a non-disabled person which is termed as 'conversion handicap' by Sen (2009).

On the other hand, disability can be a consequence of poverty. For instance, inadequate child care during infant development and exposure to dangerous working conditions due to poverty can cause disability (Filmer, 2008). Poverty can be a cause of poor health conditions that can results in disabilities (Mitra et al., 2013). For example, malnutrition can lead to disability (Maulik and Damstadt, 2007). Mitra et al. (2013) indicate that diseases whose prevalence are strongly related with poverty, less public interventions in health care provisioning, lack of access to basic amenities and bad environmental exposures can result in disability. Analysing WHO data, Stevens (2004) shows that diseases associated with poverty accounts for more than 45 per cent of the total disease burden of developing countries. Exposure to these diseases can increase the probability of disability. Less public intervention such as inadequate immunisation, providing basic health facilities also could result in disabilities among poor. As poor people mostly live in areas where there are no basic health services, they find it difficult in accessing these services (Gwatkin et al., 2007). Moreover, living in bad environmental conditions can increase the prevalence of disabilities among the poor. Poor people, mostly exposed to dangerous working conditions (Filmer, 2008), coupled with poor access to safety measures will lead to higher disability incidence among poor. Therefore, the relationship between poverty and disability is complex and poverty can be a cause as well as the result of disability.

Recent literature, mostly on developed countries suggests a stronger correlation between disability and poverty (OECD, 2009; Meyer and Mok, 2008; Parodi and Sciulli, 2008; Saunders, 2007; Gannon and Nolan, 2004). The literature on developed countries suggests that disabled people experience lower educational levels, lower employment levels, low wages and higher income poverty (Mitra, 2013). After controlling for transfers from social welfare programmes, Haveman and Wolfe (2000) find that mean income of the households with a disabled person is less than half of the mean household income of all the households in the United States.

The literature shows that disabled persons are less employed (Trani and Loeb, 2012; World Bank, 2009; Mete, 2008; Mitra and Sambamoorthi, 2009; Hoogeveen, 2005), and attain lower education (Mont and Viet Cuong, 2011; Trani and Loeb, 2012; World Bank, 2009; Mete, 2008; Rischewski et al., 2008; Hoogeveen, 2005). Furthermore, Palmer et al. (2012) and World Bank (2009) find that households with disabled persons own less assets compared to other households, while Trani and Loeb (2012) suggest that there is no such a relationship. Poverty when measured by household expenditure suggests that probability of being poor is higher with disability (Mont \& Viet Cuong, 2011; Filmer 2008; Hoogeveen, 2005). However, Rischewski et al. (2008) do not find any significant relationship between monetary poverty and disability.

The discussion above suggests that the relationship between poverty and disability is complex and disability is associated not only with monetary poverty, but also with many other aspects of life.

"[V]arious types of economic
deprivations, including malnutrition, lack
of access to health care and sanitation, may
lead to disability in developing countries.
Different types of economic deprivations
may also result from disability
including lower educational attainment,
nonemployment, lower earnings and extra
costs of living" (Mitra et al., 2013: 2).

This suggests that measuring poverty among disabled persons (or households) by monetary poverty measures may not reveal the actual situation. Therefore, the relationship between disability and poverty should be explored with multidimensional poverty approach which takes into account the different deprivations of human life. Mitra et al. (2013) apply multidimensional poverty measures developed by Alkire and Foster (2009; 2011) and compare the estimates with Bourguignon and Chakravarty (2003) measures using World Health Survey (WHS) data for 15 developing countries. They 
find that monetary poverty is clearly associated with multidimensional poverty. Disabled persons on average experience multiple deprivations at higher incidence, depth and severity than the persons without disabilities (Mitra et al., 2013). They also find that when poverty is measured by monetary measures (consumption expenditure) there is no significant relationship between disability and poverty for the same data.

\section{METHODOLOGY AND DATA}

Analysing poverty among disabled persons needs special attention to the living context of disabled persons. Disabled persons and their families encounter different hardships than the typical deprivations faced by the poor (Yeo and Moore, 2003; Zaidi and Burchardt, 2005). Therefore, this study applies both monetary poverty and multidimensional poverty measures in analysing poverty among households with disabled persons. In estimating monetary poverty, the standard Foster Greer Thorbecke (1984) (FGT) indexes, namely poverty headcount, gap and severity indexes are estimated. Multidimensional poverty measures (multidimensional poverty incidence, intensity and acute multidimensional poverty) are calculated using the standard Alkire Foster $(2009 ; 2011)$ approach to multidimensional poverty. Household income and expenditure survey (HIES) 2006/07 and $2009 / 10$ of Sri Lanka are the main data source of this study which is a national sample survey of nearly 20,000 households.

\section{Foster Greer Thorbecke measures of one-dimensional poverty}

Following the notation of Foster et al. (1984), estimating one dimensional poverty can be defined as follows;

Let $y=\left(y_{1}, y_{2}, \ldots, y_{n}\right)$ be a vector of household income in increasing order and suppose that $\mathrm{z}>0$ the predetermined poverty line. Where $\mathrm{g}_{\mathrm{i}}=\mathrm{z}-\mathrm{y}_{\mathrm{i}}$ is the income shortfall of the $i^{\text {th }}$ household $q=q(y ; z)$, is the number of poor households (whose income falls below the poverty line $\mathrm{z}$ ) and $\mathrm{n}=\mathrm{n}(\mathrm{y})$ is the total number of households. Poverty measure can be defined as

$$
P(y ; z)=\frac{1}{n z^{2}} \sum_{i=1}^{q} g_{i}^{2} \ldots
$$

In line with Sen (1976), Foster et al. (1984) also measure poverty by taking the normalised weighted sum of the income shortfall of the poor. However, in FGT method, deprivation depends on the distance between the actual income of the poor household and the poverty line. FGT method satisfies the two poverty axioms proposed by Sen $(1976 ; 1979)$, namely monotonicity and transfer axioms ${ }^{2}$.
Introducing the poverty aversion parameter to equation (1), Foster et al. (1984) develop the FGT class of poverty measures, which is denoted by

$$
P_{\alpha}(y ; z)=\frac{1}{n} \sum_{i=1}^{q}\left(\frac{g_{i}}{z}\right)^{\alpha}
$$

Where $\alpha \geq 0, \alpha$ is called the poverty aversion parameter because lager values of $\alpha$ gives greater emphasis to the poorest of the poor. By setting $\alpha=0,1$ and 2 , the standard FGT poverty measures can be generated. When $\alpha=0$, it generates the poverty headcount index which measures the incidence of poverty. When $\alpha=1$, it generates the poverty gap index which measures the depth of poverty and when $\alpha=2$, it generates the squared poverty gap index which measures the severity of poverty.

The above poverty measures are estimated on the basis of sample estimations, hence checking the statistical validity of observed estimates should lead to improve the validity of the results. Kakwani (1993) proposed a way of testing the statistical significance of observed poverty estimates of a sample and comparison between poverty figures estimated using two independent samples. Following Kakwani (1993: 634), the testing of the hypothesis of individual statistical significance and comparison of poverty figures estimated using two independent samples can be defined as follows.

Suppose that $\mathrm{P}_{\alpha}$ is a FGT class poverty measure and $\mathrm{n}$ is the sample size, then $\sqrt{n}\left(\hat{P}_{\alpha}-P_{\alpha}\right)$ asymptotically normally distributed with zero mean and variance $\sigma^{2}\left(\mathrm{P}_{\alpha}\right)$. If $\hat{\sigma}^{2}\left(P_{\alpha}\right)$ is a consistent estimator of $\sigma^{2}$ $\left(\mathrm{P}_{\alpha}\right)$ then $\hat{\sigma}^{2}\left(\hat{P}_{\alpha}\right) / \sqrt{n}$ is called the standard error of which is denoted by $\operatorname{SE}\left(\hat{P}_{\alpha}\right)$ hence

$$
t=\frac{\left(\hat{P}_{\alpha}-P_{\alpha}\right)}{S E\left(\hat{P}_{\alpha}\right)}
$$

Further, suppose that $\hat{P}_{\alpha 1}$ and $\hat{P}_{\alpha 2}$ are estimates of poverty measure $\mathrm{P}_{\alpha}$ computed using two independent samples of $n_{1}$ and $n_{2}$ respectively and let $\hat{\sigma}_{1}^{2}$ and $\hat{\sigma}_{2}^{2}$ be the sample estimators of the variances of the asymptotic distributions of $\sqrt{n_{1}} \hat{P}_{a 1}$ and $\sqrt{n_{2}} \hat{P}_{a 2}$ respectively, then the standard error of $\left(\hat{P}_{\alpha 1}-\hat{P}_{\alpha 2}\right)$ will be

$$
S E\left(\hat{P}_{\alpha 1}-\hat{P}_{\alpha 2}\right)=\sqrt{\frac{\hat{\sigma}_{1}^{2}}{n_{1}}+\frac{\hat{\sigma}_{2}^{2}}{n_{2}} \ldots \ldots \ldots \ldots \ldots \ldots \ldots \ldots \ldots \ldots(4)}
$$

And the test statistic will be,

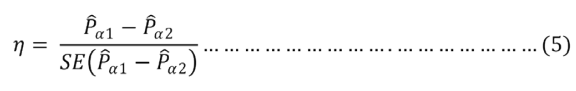

Then, $\eta$ can be used to test the null hypothesis that the observed poverty differences are statistically significant. 


\section{Alkire-Foster measures of multidimensional poverty}

Following UNDP (2010), multidimensional poverty headcount can be estimated as follows;

$$
M P H=\frac{q}{n} \ldots
$$

Where $\mathrm{q}$ is the number of people who are multidimensionally poor and $\mathrm{n}$ is the total population. Intensity of Deprivation (ID) shows the proportion of weighted indicators (d), in which on average, poor people are found to be deprived and can be calculated as follows;

$$
I D=\frac{\sum_{1}^{d} c_{i}}{q d}
$$

Where $c_{i}$ is the total number of weighted deprivations experience by the poor and $d$ is the number of indicators applied (10 in this study). It should be noted that weighted deprivations are summed and divided by the total number of indicators only for the poor households.

Alkire and Foster $(2009 ; 2011)$ and subsequently Alkire and Santos (2010) elaborate the calculation procedure of the MPI as follows. Let $\mathrm{y}=\left[\mathrm{y}_{\mathrm{ij}}\right]$ denote $\mathrm{a}$ matrix of achievements where $\mathrm{i}=$ person, $\mathrm{j}=$ dimension. Each row vector gives an individual $i^{\text {th }}$ achievement in different dimensions, while each column vector gives distribution of $\mathrm{j}^{\text {th }}$ dimension across different individuals. The MPI calculation procedure allows the assigning of different weights to different dimensions, and therefore, the weighting vector is defined as $\mathrm{w}=$ $\mathrm{w}_{\mathrm{i}}$. The sum of weights is equal to the total number of dimensions (d) given as $\sum_{j=1}^{d} w_{j}=d$. Applying the dual cut-off procedure to identify the poor, the MPI uses a 'within dimension cut-off' and an 'across dimension cut-off'. The households that are found to be poor by any dimension are identified in the first step. In the procedure, let $\mathrm{z}_{\mathrm{j}}>0$, be the poverty line (deprivation cut-off or first cut-off) in dimension j. Then $g^{0}=\left[g_{i j}^{0}\right]$ denotes a matrix of deprivations, which is defined by $g_{i j}^{0}=w_{j}$ when $y_{i j}<z_{j}$. From matrix $\mathrm{g}^{0}, \quad c_{i}=\sum_{j=1}^{d} g_{i j}^{0}$, and a column vector is constructed, which represents the sum of weighted deprivations suffered by person i. After that, applying the second cut-off $(\mathrm{k})$, multidimensional poor are identified.

Alkire and Santos (2010: 10) explain the identification procedure more formally as follows: let $\rho: R_{+}^{d *} R_{++}^{d} \rightarrow\{0,1\}, \rho_{k}$ be the identification function that maps from person i's achievement vector $y_{i} \in R_{+}^{d}$ and cut-off vector z in $R_{++}^{d}$ to an indicator variable. $\rho_{k}=1$ when $c_{i} \geq k$ and $\rho_{k}=0$ when $c_{i}<k$, which means that a person to be considered as multidimensionally poor, his or her weighted deprivation should be greater than $\mathrm{k}$. Then, censored matrix $\mathrm{g}^{0}(\mathrm{k})$ is constructed from $\mathrm{g}^{0}$ by replacing its $\mathrm{i}^{\text {th }}$ row with a vector of zeros, whenever $\rho_{k}=0$ this matrix contains weighted derivations of all persons who have been identified as poor and excludes deprivations of non-poor. The MPI is simply the mean of the matrix $\mathrm{g}^{0}(\mathrm{k})$, that is $M P I=\mu\left(g^{0}(k)\right)$ where $\mu$ denotes the arithmetic mean. In essence, the MPI is the weighted sum of the deprivations experienced by the poor, divided by the total population, multiplied by the total number of deprivations considered. In other words, MPI is the multiplication of multidimensional poverty headcount ratio (MPH) and average depreciation share (ID) among the poor.

Following Alkire and Santos (2010), this study uses 'health', 'education' and 'living standards' as the dimensions of the MPI. These three dimensions are similar to the three dimensions of the Human Development Index.

The three dimensions are estimated on the basis of ten indicators, two each to calculate the health and education dimensions and remaining six to calculate the living standards dimension. The dimensions, indicators and their cut-off points of this study are shown in the Table 2.

This study applies 'years of schooling' and 'child enrolment' as the indicators for the education dimension, and access to 'cleaner cooking fuel', 'sanitation', 'water', and 'electricity', 'type of house floor', and 'assets availability' as the indicators for the 'living standards' dimension. In the health dimension, whether the household has a chronically ill member and whether someone from the household was hospitalised during the last six months are used as the two proxies for 'nutrition' and 'child mortality' indicators. The significance of good health for wellbeing of the people is emphasised by the three MDGs, namely Goal 4, 5, and 6. Those who are ill or disabled may not be fully economically active, limiting their earning capacity (Andren, 2001; Bloom et al., 2004) and ability to make economic decisions. Furthermore, they tend to have less education and they have to bear the cost of treatments for their life time, thus trapping them in poverty (van Agt et al., 2000; Oxford Health Alliance, 2005). Being sick may affect a person's working life, social life, lifestyles as well as emotional aspects (Vingard et al., 2004; Hansen, 2000). Although these two proxies may not fully capture the health deprivations of the household, these two variables are the best available proxies in the HIES 2006/07 and 2009/10.

Whether someone in the household has 'at least five years of school education', and 'all children of school age are attending school' are the indicators used to 
calculate the education dimension. School education can be a proxy for the knowledge and understanding of the household. A higher education (literacy, numeracy and understanding) boosts the functioning of the household (UNESCO, 2002; 2003; Wedgwood, 2007; Boissiere et al., 1990). The importance of education in poverty reduction is also highlighted by the MDG 2 on education. If a child is not attending school, all the members of the household are considered as poor by the indicator. A school aged child is defined as a child who is between age 5 and age 12 (grade 1 to grade 8 in Sri Lanka).
Access to 'clean drinking water', 'improved sanitation', 'clean cooking fuel', 'electricity', 'type of flooring material' and 'assets ownership' are the six indicators applied for the 'living standards' dimension. Even though these are means, they are directly connected to the functionings of the households. Access to clean drinking water, sanitation, clean cooking fuel, and better flooring material are related to better health. Clean cooking fuel prevents respiratory diseases, which is a cause for preventable death and better environment at home. Electricity provides a safer means of lighting,

Table 2: Dimensions, indicators, cut-offs and relevance to MDGs

\begin{tabular}{|c|c|c|c|}
\hline Dimension & Indicator & Cut-off (poor if......) & Related to \\
\hline \multirow{2}{*}{ Education } & Schooling & No one has completed grade 5 & MDG 2 \\
\hline & Child enrolment & School aged child is not attending school (grade 1 to 8 ) & MDG 2 \\
\hline \multirow[b]{2}{*}{ Health } & Chronically ill & Household member is chronically ill & MDG 6 \\
\hline & Hospitalized & $\begin{array}{l}\text { Household member was hospitalized within the last six } \\
\text { months }\end{array}$ & MDG 6 \\
\hline \multirow[b]{3}{*}{ Standard } & Electricity & Household has no access to electricity & \\
\hline & Sanitation & $\begin{array}{l}\text { Sanitation facility of the household is not improved or } \\
\text { shared with others }\end{array}$ & MDG 7 \\
\hline & Water & $\begin{array}{l}\text { Household has no access to clean water (as defined by the } \\
\text { MDG) or walks more than } 30 \mathrm{~min} \text {. to get clean water }\end{array}$ & MDG 7 \\
\hline \multirow{3}{*}{ of living } & Floor & Household has mud or cow dung floor & \\
\hline & Cooking fuel & $\begin{array}{l}\text { Household uses firewood, saw dust or paddy husk as } \\
\text { cooking fuel }\end{array}$ & MDG 7 \\
\hline & Assets & $\begin{array}{l}\text { Household does not own at least two of: radio, TV, } \\
\text { telephone, bicycle or motorcycle or tractor }\end{array}$ & \\
\hline
\end{tabular}

Table 3: Distribution of sampling units of HIES 2009/10

\begin{tabular}{lcclcc}
\hline District & Households & $\%$ & District & Households & $\%$ \\
\hline Colombo & 2404 & 12.05 & Batticaloa & 778 & 3.90 \\
Gampaha & 1708 & 8.56 & Ampara & 772 & 3.81 \\
Kalutara & 1377 & 6.90 & Trincomalee & 565 & 2.83 \\
Kandy & 1010 & 5.06 & Kurunegala & 1066 & 5.34 \\
Matale & 587 & 2.94 & Puttalam & 780 & 3.91 \\
N u w a r a & 615 & 3.08 & Anuradhapura & 750 & 3.76 \\
Eliya & & & & & \\
Galle & 1480 & 7.42 & Polonnaruwa & 525 & 2.63 \\
Matara & 1229 & 6.16 & Badulla & 743 & 3.72 \\
Hambantota & 804 & 4.03 & Monaragala & 492 & 2.47 \\
Jafna & 333 & 1.67 & Ratnapura & 871 & 4.36 \\
Vavuniya & 328 & 1.64 & Kegalle & 741 & 3.71 \\
\hline Area & Households & $\%$ & Area & Households & $\%$ \\
\hline Urban & 5273 & 26.42 & Estate & 1736 & 8.70 \\
Rural & 12949 & 64.88 & Sri Lanka & 19958 & 100.00 \\
\hline
\end{tabular}

Source: Department of Census and Statistics of Sri Lanka (2011) 
makes households independent and mobile at night, and gives access to safer food through refrigeration. Moreover, the application of these indicators to measure living standards is also well justified by MDG 7 .

Relative weights assigned to the indicators are chosen on the basis of value judgments and could "represent the enduring importance of a capability relative to the other capabilities or the priority of expanding one capability relative to the others in the next phase" (Alkire and Santos, 2010: 18). Choosing weights could be done through participatory approach, survey questions or public debate. However, there should be a consensus among relevant communities (Sen, 1996; Alkire and Santos, 2010). The MPI assigns equal weights to all the dimensions, thus $1 / 3$ for each. The indicators for the health and education dimensions have the same weights $(1 / 6)$ and the indicators for the living standards dimension have 1/18. Kumara (2013) suggests that statistical weights for different dimensions can be allocated using a principal component analysis. However, due to the interpretation difficulties of this method, principal component analysis based statistical weights are not employed in this study.

The poverty cut-off proposed by Alkire and Santos (2010), which is 30 per cent $(\mathrm{k}=3)$ of the total value of weighted indicators, is applied in this study. This is an intermediate criterion, which aimed at overcoming the problems of the union and intersection criteria. A household is multidimensionally poor if the total value of weighted deprivations sums up to 30 per cent or higher.

\section{Data}

Household Income and Expenditure Survey (HIES) 2006/07 and 2009/10 of Sri Lanka is the primary data source of this study. The HIES is a national survey conducted once every five years (presently once every three years), starting from 1980/81 by the Department of Census and Statistics (DCS) of Sri Lanka.

The sample size of the HIES 2006/07 was 21,790 households and 19,958 households in 2009/10 and was conducted for 12 months to adjust for seasonal variations. Two stage random sampling method is applied for the sample design. Urban, rural and estate areas are the domains of stratification (Department of Census and Statistics, 2008). Table 3 shows the sample distribution of HIES 2009/10 across districts.

The HIES micro data are widely used by poverty researchers, especially for the estimations of monetary poverty in Sri Lanka, and no major problems or inaccuracies have been reported (World Bank, 2007).
The survey gathers a wide range of socio-economic information at individual and household levels, such as information on households' demography, schooling, health, expenditure, income, debts, housing, access to facilities and assets availability.

A household is categorised as a household with disabled person(s) if the household reported that they have a disabled member who has moving difficulties, mental retardation or has disability in seeing. 6.4 per cent of households reported that they had at least one member of disabled persons in the household in 2006/07 and 5.88 in 2009. The rate of disabled households reported in this survey is similar to the rates reported in 2001 population census of Sri Lanka (DCS, no date.). Table 4 shows the distribution of sample sizes among different areas (see Appendix: Table I for data summaries).

\section{RESULTS AND DISCUSSION}

\section{Monetary poverty}

Three standard FGT poverty measures, namely poverty headcount ratio, poverty gap ratio and squared poverty gap ratio are estimated at urban, rural, estate and national levels for 2006/07 and 2009/10. The estimates are shown by Table 5 .

Prevalence of monetary poverty among households with disabled persons is significantly higher than the prevalence of monetary poverty among the households without disabled persons. The higher monetary poverty levels among households with disabled persons compared to households without disabled persons can be seen at the national level as well as in urban, rural and estate areas. Monetary poverty among households with disabled persons in estate areas is the highest in 2006/07- as the case with national poverty levels- followed by rural and urban areas, respectively. However, monetary poverty among households with disabled persons in estate areas $^{3}$ is lesser than the monetary poverty among households without disabled persons in the recent survey. But as shown by Table 6 , the difference of monetary poverty between households with and without disabled persons is not statistically significant in estate areas in the recent survey. Rural areas record the highest poverty among households with disabled persons in the recent survey followed by estate and urban areas, respectively.

Poverty gap index, which measures the depth of poverty, shows that poor households with disabled persons are poorer (further away from the poverty line) than the poor households without disabled persons. The poverty gap index of the households with disabled persons is around 40 per cent higher than the poverty 
Table 4: Distribution of sample sizes by different areas

\begin{tabular}{|c|c|c|c|c|c|c|c|c|c|}
\hline \multirow{2}{*}{ Survey year } & \multirow{2}{*}{ Sample } & \multicolumn{2}{|c|}{ Urban } & \multicolumn{2}{|c|}{ Rural } & \multicolumn{2}{|c|}{ Estate } & \multicolumn{2}{|c|}{ Total } \\
\hline & & HHs & $\%$ & HHs & $\%$ & HHs & $\%$ & HHs & $\%$ \\
\hline \multirow{3}{*}{$2006 / 07$} & With disabled & 226 & 18.94 & 882 & 73.93 & 85 & 7.12 & 1,193 & 100.0 \\
\hline & Without disabled & 4,407 & 25.40 & 11,307 & 65.17 & 1,637 & 9.43 & 17,351 & 100.0 \\
\hline & Total & 4,633 & 24.98 & 12,189 & 65.73 & 1,722 & 9.29 & 18,544 & 100.0 \\
\hline \multirow{3}{*}{$2009 / 10$} & with disabled & 269 & 22.91 & 796 & 67.80 & 109 & 9.28 & 1,174 & 100.0 \\
\hline & without disabled & 5,004 & 67.80 & 12,153 & 64.70 & 1,627 & 8.66 & 18,784 & 100.0 \\
\hline & Total & 5,273 & 26.42 & 12,949 & 64.88 & 1,736 & 8.70 & 19,958 & 100.0 \\
\hline
\end{tabular}

Source: Author's compilation using HIES 2006/07 and 2009/10

Table 5: Foster Greer Thorbecke (FGT) poverty estimates

\begin{tabular}{|c|c|c|c|c|c|c|c|}
\hline \multirow{2}{*}{ Sample } & \multirow{2}{*}{ Area } & \multicolumn{3}{|c|}{$2006 / 07$} & \multicolumn{3}{|c|}{$2009 / 10$} \\
\hline & & $\mathrm{HCI}$ & PGI & SPGI & $\mathrm{HCI}$ & PGI & SPGI \\
\hline \multirow{4}{*}{ All Households } & Urban & $5.7 * * *$ & $1.1 * * *$ & $0.3 * * *$ & $4.0 * * *$ & $0.8 * * *$ & $0.2 * * *$ \\
\hline & Rural & $16.0 * * *$ & $3.0 * * *$ & $0.9 * * *$ & $9.4 * * *$ & $1.7 * * *$ & $0.5 * * *$ \\
\hline & Estate & $30.1 * * *$ & $5.6 * * *$ & $1.6 * * *$ & $14.7 * * *$ & $2.5 * * *$ & $0.7 * * *$ \\
\hline & National & $15.3^{* * *}$ & $2.9 * * *$ & $0.8 * * *$ & $8.9 * * *$ & $1.6^{* *}$ & $0.5 * * *$ \\
\hline \multirow{4}{*}{$\begin{array}{l}\text { Households with disabled } \\
\text { Person(s) }\end{array}$} & Urban & $7.1 * * *$ & $1.8 * *$ & $0.6^{* *}$ & $10.0 * * *$ & $1.3 * * *$ & $0.3 * *$ \\
\hline & Rural & $24.9 * * *$ & $4.7 * * *$ & $1.4 * * *$ & $16.8 * * *$ & $3.7 * * *$ & $1.2 * * *$ \\
\hline & Estate & $32.8 * * *$ & $6.9 * * *$ & $2.2 * * *$ & $10.3 * * *$ & $2.1 * * *$ & $0.7^{* *}$ \\
\hline & National & $23.4 * * *$ & $4.5 * * *$ & $1.4 * * *$ & $15.7 * * *$ & $3.3 * * *$ & $1.1 * * *$ \\
\hline \multirow{4}{*}{$\begin{array}{l}\text { Households without disabled } \\
\text { person(s) }\end{array}$} & Urban & $5.6 * * *$ & $1.0 * * *$ & $0.3 * * *$ & $3.7 * * *$ & $0.8 * * *$ & $0.2 * * *$ \\
\hline & Rural & $15.3^{* * *}$ & $2.9 * * *$ & $0.9 * * *$ & $9.0 * * *$ & $1.6 * * *$ & $0.5 * * *$ \\
\hline & Estate & $30.0 * * *$ & $5.5 * * *$ & $1.6 * * *$ & $15.0 * * *$ & $2.6^{* *}$ & $0.7 * * *$ \\
\hline & National & $14.7 * * *$ & $2.8 * * *$ & $0.8 * * *$ & $8.5 * * *$ & $1.5 * * *$ & $0.5 * * *$ \\
\hline
\end{tabular}

Source: Author's estimations using HIES 2006/07 and 2009/10.

Note; $* *$ significant at 95\% level, *** significant at 99\% level, HCI: headcount index, PGI: poverty gap index, SPGI: squared poverty gap index

Table 6: Statistical significance of poverty differences between households with and without disabled persons ( $\eta$ )

\begin{tabular}{|c|c|c|c|c|c|c|}
\hline \multirow{2}{*}{ Area } & \multicolumn{3}{|c|}{$2006 / 07$} & \multicolumn{3}{|c|}{$2009 / 10$} \\
\hline & $\mathrm{HCI}$ & PGI & SPGI & $\mathrm{HCI}$ & PGI & SPGI \\
\hline Urban & $14.83 * * *$ & $16.72 * * *$ & $18.09 * * *$ & $2.36 * *$ & $24.23 * * *$ & $10.48 * * *$ \\
\hline Rural & $178.39 * * *$ & $137.46 * * *$ & $108.23 * * *$ & $5.90 * * *$ & $138.10^{* * *}$ & $111.35 * * *$ \\
\hline Estate & $4.38 * * *$ & $7.76^{* * *}$ & $8.10 * * *$ & 1.23 & $6.92 * * *$ & 0.40 \\
\hline National & $210.22 * * *$ & $169.22 * * *$ & $136.94 * * *$ & $6.17 * * *$ & $171.55^{* * *}$ & $137.38 * * *$ \\
\hline
\end{tabular}

Source: Author's estimations using HIES 2006/07 and 2009/10.

Note; $* *$ significant at 95\% level, *** significant at 99\% level, HCI: headcount index, PGI: poverty gap index, SPGI: squared

poverty gap index

gap index of the households without disabled persons. This high intensity of monetary poverty can also be seen at national as well as all the areas other than the estate areas. This suggests that the alleviation of monetary poverty among households with disabled persons needs more resources than that of the poor households without disabled persons.

The squared poverty gap index, which measures the inequality among the poor, shows the similar trend of headcount and poverty gap indexes. Inequality among the poor households with disabled persons is also significantly higher than the households without disabled persons. Estate areas report the highest inequality among poor households with disabled persons in 2006/07 while the rural areas show the highest inequality in 2009/10.

Monetary poverty level among households with disabled persons is 37 per cent higher than the poverty level among households without disabled persons in 2006/07 at national level. However, it further increased to more than 45 per cent in 2009/10. This increase in the ratio of monetary poverty between households with and without disabled persons is mainly due to the increased 
monetary poverty levels of the urban households with disabled persons (Table 7). Poverty gap and squared poverty gap indexes of poor households with disabled persons also show the similar pattern of differences when compared with the poverty gap and squared poverty gap indexes of the poor households without disabled persons.

In line with the national poverty trends, monetary poverty among households with disabled persons also decreased at national and all the areas other than urban areas between the two survey periods. Prevalence of monetary poverty among households with disabled persons decreased by 68 per cent in the estate areas during the two survey periods. The higher reduction of monetary poverty in estate areas could also be seen in the full sample. This higher reduction of poverty in the estate areas could be due to significant increase of their wages and lower food prices in the estate areas (DCS 2011). However, monetary poverty headcount ratio of the households with disabled persons in urban areas which is 7.1 per cent in 2006/07 increased up to 10.0 per cent in $2009 / 10$. This can mainly be due to the internal migration of the disabled persons. Disabled persons tend to move into urban areas for several reasons as their income levels increased; better accessibility to health facilities, better accessibility to special education and vocational training facilities and also for specific employment opportunities like selling lotteries and begging.

Nevertheless, poverty gap index and squared poverty gap index of the urban areas show a significant decrease between the two survey periods. This indicates that

Table 7: Percentage change of monetary poverty 2006/07-2009/10

\begin{tabular}{lllll}
\hline Sample & Area & HCI & PGI & SPGI \\
\hline & Urban & -29.2 & -24.4 & -20.5 \\
All Households & Rural & -40.9 & -43.0 & -42.1 \\
& Estate & -51.2 & -54.8 & -55.3 \\
& National & -41.5 & -43.5 & -42.5 \\
\hline & Urban & 40.9 & -26.7 & -50.9 \\
Households with disabled & Rural & -32.3 & -22.6 & -14.8 \\
Person(s) & Estate & -68.6 & -69.9 & -67.4 \\
& National & -32.8 & -26.6 & -20.8 \\
\hline & Urban & -25.9 & -24.0 & -17.0 \\
Households without disabled person(s) & Rural & -41.3 & -44.8 & -44.6 \\
& Estate & -49.8 & -53.6 & -54.5 \\
& National & -42.1 & -44.9 & -44.4 \\
\hline
\end{tabular}

Source: Author's estimations using HIES 2006/07 and 2009/10.

Note; HCI: headcount index, PGI: poverty gap index, SPGI: squared poverty gap index

Table 8: Multidimensional poverty estimates

\begin{tabular}{llrrrrrrr}
\hline \multirow{2}{*}{ Sample } & \multirow{2}{*}{ Area } & \multicolumn{3}{c}{$2006 / 07$} & & \multicolumn{3}{c}{$2009 / 10$} \\
\cline { 3 - 8 } & & MPH & ID & MPI & MPH & ID & MPI \\
\hline \multirow{3}{*}{ All Households } & Urban & 2.83 & 0.39 & 0.01 & 2.24 & 0.38 & 0.01 \\
& Rural & 6.41 & 0.38 & 0.02 & 4.97 & 0.38 & 0.02 \\
& Estate & 26.71 & 0.41 & 0.11 & 19.07 & 0.39 & 0.08 \\
& National & 7.40 & 0.39 & 0.03 & 5.48 & 0.38 & 0.02 \\
\hline \multirow{3}{*}{ Households with disabled } & Urban & 7.80 & 0.45 & 0.03 & 2.97 & 0.38 & 0.01 \\
Person(s) & Rural & 9.64 & 0.39 & 0.04 & 6.41 & 0.37 & 0.02 \\
& Estate & 62.35 & 0.46 & 0.29 & 24.77 & 0.38 & 0.09 \\
& National & 12.91 & 0.42 & 0.05 & 7.33 & 0.37 & 0.03 \\
\hline & Urban & 2.61 & 0.38 & 0.01 & 2.20 & 0.38 & 0.01 \\
Households without disabled person(s) & Rural & 6.16 & 0.38 & 0.02 & 4.88 & 0.38 & 0.02 \\
& Estate & 24.86 & 0.40 & 0.10 & 18.68 & 0.40 & 0.07 \\
& National & 7.20 & 0.39 & 0.03 & 5.36 & 0.39 & 0.02 \\
\hline
\end{tabular}

Source: Author's estimations using HIES 2006/07 and 2009/10.

Note; MPH: multidimensional poverty headcount index, ID: intensity of deprivations, MPI: multidimensional poverty index 
irrespective of the increased poverty prevalence, intensity and severity of monetary poverty among disabled persons decreased between the two survey periods. However, the rate of reduction of monetary poverty prevalence, intensity and severity among households with disabled persons is significantly lesser than the reduction of monetary poverty among households without disabled persons. Poverty headcount of the households without disabled persons decreased by 42 per cent between the two survey periods at national level, while it only decreased by 32 per cent among households with disabled persons. Importantly as discussed previously, instead of decreasing headcount ratio, urban areas show a significant increase in the poverty headcount ratio among the households with disabled persons. This is a very important finding for policy formation for the reduction of poverty among the remaining poor in Sri Lanka. Unless specific programmes are developed targeting at reducing monetary poverty among disabled persons, alleviating poverty in Sri Lanka will not be achieved soon.

\section{Multidimensional poverty}

Three multidimensional poverty indexes presented in Alkire and Santos (2010) are estimated for the total sample as well as for different areas using the HIES 2006/07 and 2009/10 primary data and presented in Table 8 . These three multidimensional poverty indexes, namely multidimensional poverty headcount index (MPH), intensity of deprivations (ID) and multidimensional poverty index (MPI) are analogues to the FGT poverty headcount, gap and severity indexes.

Table 8 confirms that poverty levels among households with disabled persons are significantly higher than that of the poverty levels among households without disabled persons, even if it is measured by multidimensional approach to poverty. Multidimensional poverty headcount of the households with disabled persons is nearly 13 per cent at the national level while it is around seven per cent for the households without disabled persons in 2006/07. Though the gap of multidimensional poverty headcount index between households with and without disabled persons decreased, 2009/10 sample also shows that there is a significant difference between the estimated poverty levels between households with and without disabled persons. Prevalence of multidimensional poverty among households with disabled persons at estate areas is considerably higher than the other areas. This is true even for the households without disabled persons. This finding is similar to the findings of Kumara (2013; 2011), Alkire and Santos (2010) and UNDP (2010). This suggests that even though the monetary poverty levels in estate areas are substantially decreased in recent past, people in these areas are deprived of other aspects of wellbeing, such as access to education, health and basic facilities. Prevalence of multidimensional poverty among households with disabled persons in urban population is significantly low especially in the latter sample. This is also a fact in other samples as well. This confirms that although the earning ability of urban poor is reduced to some extent, they have access to better health, education and basic utilities compared to their counterparts in the rural and estate areas.

Intensity of deprivation, which measures the proportion of dimensions in which households are deprived, shows that Sri Lankan poor are deprived of around 40 per cent of the concerned dimensions. Households with disabled persons record a relatively higher proportion of average deprivations compared to households without disabled persons irrespective of the area of living. However, households with disabled persons in urban and estate areas show a higher proportion of average deprivations compared to national and rural areas especially in the former sample.

Multidimensional poverty index, which takes into account the prevalence and intensity of multidimensional poverty, is applied to estimate the acute multidimensional poverty. On average, Sri Lanka reports a small value (which is closer to zero) of multidimensional poverty index as per Kumara $(2013$; 2011), Alkire and Santos (2010), and UNDP (2010). Noticeably, households with disabled persons in the estate areas show a significantly higher value of multidimensional poverty index. This signifies that disabled and multidimensionally poor people in the estate areas have poorer access to health, education, housing and household utilities. This higher value of multidimensional poverty index is mainly due to the higher rate of prevalence of multidimensional poverty in the estate areas.

Multidimensional poverty levels are significantly lower when compared with the monetary poverty levels for all the areas and both survey years. This is mainly due to the public welfare provisions of Sri Lanka. Sri Lanka provides universal free health care, free education and access to highly subsidised public utilities. This fact allows everyone to access basic facilities irrespective of the poverty or income conditions. Therefore, Sri Lanka reports relatively higher values of monetary poverty and relatively lower values of multidimensional poverty which is extensively discussed by Kumara (2011).

Even though the multidimensional poverty levels are relatively lower than the monetary poverty rates, the 
poverty difference between households with and without disabled persons is significantly higher when measured by multidimensional approach. Multidimensional poverty prevalence among households with disabled persons is twice that of the multidimensional poverty prevalence of the households without disabled persons in the former sample. However, the difference of multidimensional poverty prevalence between households with and without disabled persons is relatively lower in the latter sample. This is mainly due to implementation of different welfare projects by government as well as nongovernment institutions to uplift the living conditions among the disabled persons. Sri Lanka established National Council and National Secretariat for Persons with Disabilities (NSPD) in the Ministry of Social Services to operationalise the provisions of the Disability
Act of 1996 with the development of the national policy for Sri Lanka on disabled persons. After establishing the NSPD, government provided about US \$25 per month as a welfare grant to families with disabled persons. A mobile service providing wheelchairs and tricycles, a grant for self-employment (about US \$200), one time medical assistance (about US \$150), housing assistance (US \$ 2000), building houses for disabled families, and educational grants for disabled persons are some other programmes operated by the NSPD.

However, the difference in intensity of multidimensional poverty between households with and without disabled persons is significantly low, which means that irrespective of disability conditions poor households face equal number of deprivations. The

Table 9: Percentage change 2006/07-2009/10

\begin{tabular}{|c|c|c|c|c|}
\hline Sample & Area & $\mathrm{MPH}$ & ID & MPI \\
\hline \multirow{4}{*}{ All Households } & Urban & 20.85 & 0.59 & 21.31 \\
\hline & Rural & 22.46 & 0.84 & 23.12 \\
\hline & Estate & 28.60 & 3.14 & 30.84 \\
\hline & National & 25.95 & 1.73 & 27.23 \\
\hline \multirow{4}{*}{$\begin{array}{l}\text { Households with disabled } \\
\text { Person(s) }\end{array}$} & Urban & 61.92 & 16.28 & 68.12 \\
\hline & Rural & 33.51 & 4.52 & 36.51 \\
\hline & Estate & 60.27 & 18.17 & 67.49 \\
\hline & National & 43.22 & 11.00 & 49.47 \\
\hline \multirow{4}{*}{ Households without disabled person(s) } & Urban & 15.71 & -1.86 & 14.14 \\
\hline & Rural & 20.78 & 0.46 & 21.14 \\
\hline & Estate & 24.86 & 1.08 & 25.67 \\
\hline & National & 25.56 & 0.58 & 25.99 \\
\hline
\end{tabular}

Source: Author's estimations using HIES 2006/07 and 2009/10.

Note; MPH: multidimensional poverty headcount index, ID: intensity of deprivations, MPI: multidimensional poverty index

Table 10: Contribution from each dimension to the acute multidimensional poverty

\begin{tabular}{|c|c|c|c|c|c|c|c|}
\hline \multirow{3}{*}{ Sample } & \multirow{3}{*}{ Area } & \multicolumn{3}{|c|}{$2006 / 07$} & \multicolumn{3}{|c|}{$2009 / 10$} \\
\hline & & Health & Education & Living & Health & Education & Living \\
\hline & & & & Standards & & & Standards \\
\hline \multirow{4}{*}{ All Households } & Urban & 40.26 & 29.37 & 30.36 & 41.18 & 29.11 & 29.97 \\
\hline & Rural & 29.94 & 27.83 & 42.23 & 31.45 & 28.45 & 40.10 \\
\hline & Estate & 19.73 & 35.72 & 44.56 & 19.25 & 36.21 & 44.54 \\
\hline & National & 27.35 & 31.07 & 41.92 & 28.68 & 31.10 & 40.39 \\
\hline \multirow{4}{*}{$\begin{array}{l}\text { Households } \\
\text { with disabled } \\
\text { Person(s) }\end{array}$} & Urban & 46.51 & 32.56 & 20.93 & 50.00 & 27.78 & 22.22 \\
\hline & Rural & 24.12 & 33.67 & 42.24 & 27.19 & 34.21 & 38.60 \\
\hline & Estate & 17.77 & 47.83 & 34.40 & 9.84 & 45.90 & 44.26 \\
\hline & National & 24.21 & 38.88 & 36.91 & 23.83 & 37.31 & 38.86 \\
\hline \multirow{4}{*}{$\begin{array}{l}\text { Households } \\
\text { without } \\
\text { disabled } \\
\text { person(s) }\end{array}$} & Urban & 39.23 & 28.85 & 31.92 & 40.26 & 29.21 & 30.52 \\
\hline & Rural & 30.67 & 27.10 & 42.23 & 31.81 & 27.97 & 40.22 \\
\hline & Estate & 20.02 & 33.91 & 46.07 & 20.05 & 35.39 & 44.56 \\
\hline & National & 27.78 & 29.61 & 42.61 & 29.08 & 30.45 & 40.51 \\
\hline
\end{tabular}

Source: Author's estimations using HIES 2006/07 and 2009/10 
equality of intensity of deprivations between households with and without disabled persons further increased in the latter survey. However, difference in acute multidimensional poverty between households with and without disabled persons is relatively high compared to the multidimensional intensity.

All these suggest that multidimensional poverty among households with disabled persons is significantly higher than the households without disabled persons. This is due to the fact that disabled people face different circumstances in accessing health education and other basic facilities. Even though the provision of health and education is universally free, still disabled persons have to spend additional time and money for accessing these services. Sometimes even if services are available, there are no facilities for disabled people such as special school facilities for the visually impaired students.

Reduction of multidimensional poverty during the two survey periods is relatively low compared to the reduction in monetary poverty during the same period. However, reduction in prevalence of multidimensional poverty among households with disabled persons is considerably high between the two survey periods. Although the national multidimensional headcount ratio decreased by 25 per cent, it decreased by more than 43 per cent among households with disabled persons. Moreover, reduction of multidimensional poverty headcount among households with disabled persons is more than 60 per cent in estate and urban areas. Even though the intensity of deprivation marginally decreased, acute multidimensional poverty decreased by half due to the reduction in headcount ratio. Estate areas show the highest reduction of multidimensional poverty in any index. The same trend could be observed with the monetary poverty indexes.

Multidimensional poverty index allows the calculation of contributions from different components to the acute multidimensional poverty, which is important in policy development. Table 10 shows that, as expected, living standards dimension contributes the most to the multidimensional poverty in Sri Lanka.

However, a notable difference is that health dimension contributes the most to the multidimensional poverty in urban areas. This is due to the fact that the education and utilities are much better in urban Sri Lanka. Urban areas host the best schools as well as other educational facilities. Availability of public utilities and other services is high in the urban areas. These facts reduce the contribution from education and living standards dimension to the acute multidimensional poverty.
On the other hand, most of the ill and disabled people move into urban areas, which generate higher contribution from health dimension. Since the best hospitals are available in the urban areas, people migrate from other areas to the urban areas to get access for these health facilities. As discussed previously, disabled people also move into urban areas in search of special educational, vocational, and health facilities as well as employment. This has led to higher contribution from health dimension to the acute multidimensional poverty.

Another important finding of this research is that education contributes more to the acute multidimensional poverty among households with disable persons compared to the households without disabled persons. This is true for national as well as other samples and for the two survey years as well. This signifies that access to education for disabled people is limited and it has led to a higher level of multidimensional poverty among disabled persons. As discussed previously, this signifies that even though education is free in Sri Lanka, the special educational facilities for disabled persons is not yet available or not accessible for them.

\section{CONCLUSION}

This study applied three standard monetary poverty indexes and their multidimensional counterparts to estimate poverty among households with disabled persons. The study found that irrespective of the analytical method applied, poverty among households with disabled persons is significantly higher than the poverty among households without disabled persons. This was true for prevalence, depth and severity of poverty for both survey years and at the national level as well as other areas (urban, rural and estate). Poverty, when measured by multidimensional approach, is relatively low in Sri Lanka due to the welfare provisions of the government. However, differences of estimated poverty levels between households with and without disabled persons are high when estimated using multidimensional approach. This suggests that households with disabled persons encounter different problems other than the low monetary earnings. Depth and severity of monetary poverty among households with disabled persons is also higher than the households without disabled persons. This indicates that the living conditions of the disabled poor are worse than that of the poor persons without disabilities. Alleviation of poverty among households with disabled persons needs additional resources and emphasis.

Poverty decreased significantly between the two survey periods irrespective of the analytical method 
applied. A huge reduction of monetary as well as multidimensional poverty in the estate areas can be observed. Reduction of prevalence of monetary poverty among households with disabled persons is lesser than the reduction of poverty in households without disabled persons. This suggests that income generating abilities of disabled persons are not yet improved, compared to people without disability. On the contrary, reduction of prevalence of multidimensional poverty among households with disabled persons is higher than the other households. This suggest that though the income earning ability of disabled persons is not improved, the provision of other facilities such as housing, health and education has contributed for the reduction of multidimensional poverty among disabled.

As found in previous studies (Kumara, 2011; 2013), 'living standards' dimension contributes to much of the multidimensional poverty in Sri Lanka. However, contribution from the 'health' dimension to the multidimensional poverty is relatively high for the urban areas. Importantly, contribution from the three dimensions considered in this research is almost the same for the households with disabled persons at national and other areas, except estate areas. Hence, further reduction of poverty in Sri Lanka, especially alleviating poverty among households with disabled persons, requires improvements in all the three dimensions of health, education and living standards.

\section{END NOTES}

1. HDI value 0.75 (ranked 73 ), life expectancy at birth 74.3, adult literacy 91.2, primary enrolment 99, secondary enrolment 99, maternal mortality 35 , infant mortality 8 , child mortality 10 , gender inequality index 0.38 (Human Development Report, 2014).

2. Monotonicity axiom: given other things, a reduction in the income of poor household must increase the poverty measure. Transfer axiom; given other things, a pure transfer of income from a poor household to any other household that is richer must increase the poverty measure.

3. The estate areas historically are comprised of the families in the tea, rubber and coconut plantations. At present, the areas remain mainly with the families of tea estate workers who are the second and third generations of the imported labourers from India until 1940 by the British colonials. They mainly speak Tamil and own different cultural attributes.

\section{REFERENCES}

Alkire, S. and Foster, J (2011) Counting and multidimensional poverty measurement, Journal of Public Economics, 95 (7-8), pp: 476-487.

DOI: https://doi.org/10.1016/j.jpubeco.2010.11.006

Alkire, S. and Foster, J. (2009) Counting and multidimensional poverty measurement, In von Braun, J., Hill, R. V. \& PandyaLorch, R. (eds.) The poorest and hungry: assessments, analyses, and actions, pp: 77-90, Washington, DC: International Food Policy Research Institute.

Alkire, S. and Santos, M. E. (2010) Acute Multidimensional Poverty: a new index for developing countries, Background paper for the 2010 Human Development Report, UNDP.

Andren, D. (2001) Work, sickness, earnings, and early exits from the labor market: an empirical analysis using Swedish longitudinal data, Economic Studies, 107, Department of Economics, Göteborg University.

Bloom, D. E., Canning, D. and Jamison, D. (2004) Health, Wealth, and Welfare, Finance and Development, Washington, DC: The International Monetary Fund.

Boissiere, M., Knight, J. B. and Sabot, R. H. (1985) Earnings, schooling, ability and cognitive skills, The American Economic Review. 75 (5), pp: 1016-1030.

Bourguignon, F. and Chakravarty, S. R. (2003) The measurement of multidimensional poverty, Journal of Economic Inequality, 1, pp: 5-49.

DOI: https://doi.org/10.1023/A:1023913831342

Braithwaite, J. and Daniel, M. (2009) Disability and poverty: a survey of World Bank poverty assessments and implications, ALTER - European Journal of Disability Research/Revue Europe'enne de Recherche sur le Handicap, 3(3), pp: 219-232.

Campbell, F. K. (2007) Disability, law and mobilisation in Sri Lanka, paper presented at the Socio-Legal Studies Association (UK) Annual Conference; hosted by the Kent Law School, Canterbury, United Kingdom, 3-5 April 2007.

DOI: https://doi.org/10.2139/ssrn.1626534

Culyer, A. J. and Newhouse, J. P. (eds.) Handbook of Health Economics, Vol. 1, Elsevier Science B.V.

De Silva, W. I., Amarabandu, W. P. and Gunnsekera, H. R. (2008) Disability among elderly in Sri Lanka: comparison of disability rates in the census of 1981 - 2001, Colombo Sri Lanka: Institute for Health Policy.

De Silva, W. I., Amarabandu, W. P. and Gunasekara, H. R. (2007) Disability amongst the elderly in Sri Lanka, Research Studies Series Number 1, Colombo Sri Lanka: Institute for Health Policy. 
Filmer, D. (2008) Disability, poverty and schooling in developing countries: results from 14 household surveys, World Bank Economic Review, 22(1), pp: 141-163.

DOI: https://doi.org/10.1093/wber/lhm021

Foster, J. Greer, J. and Thorbecke, E. (1984) Notes and comments: a class of decomposable poverty measures, Econometrica, 52 (3), pp: 761-766.

DOI: https://doi.org/10.2307/1913475

Gannon, B. and Nolan B. (2004) Disability and labour market participation in Ireland, Economic and Social Review, 35(2), pp: $135-155$.

Gertler, P. and Gruber, J. (2002) Insuring consumption against illness, American Economic Review, 92(1), pp: 51-70.

DOI: https://doi.org/10.1257/000282802760015603

Government of Sri Lanka (1996) Protection of the Rights of Persons with Disabilities Act, No. 8 of 1996, Colombo, Sri Lanka: Parliament of the Democratic Socialist Republic of Sri Lanka.

Government of Sri Lanka (2003) National Policy on Disability for Sri Lanka, Colombo, Sri Lanka: Ministry of Social Welfare.

Gunatilaka, R. and Chotikapanich, D. (2006) Inequality trends and determinants in Sri Lanka 1980-2002, Working Paper No 6/06. Victoria: Department of Econometrics and Business Statistics, Monash University.

Gwatkin, D. R., Rutstein, S., Johnson, K., Suliman, E., Wagstaff, A. and Amouzou, A. (2007) Socioeconomic differences in health, nutrition, and population within developing countries, Working Paper 30544, Washington, DC: World Bank.

Hansen, J. (2000) The effect of work absence on wages and wage gaps in Sweden, Journal of Population Economics, 13 (1), pp: 45-55.

DOI: https://doi.org/10.1007/s001480050122

Haveman, R. and Wolfe, B. (2000) The economics of disability and disability policy, In Haveman, R., Karen, H., Wolfe, B., Smith, P. and Wilson, K. (eds.) The Changing Economic Status of U.S. Disabled Men: Trends and Their Determinants, 19821991. Empirical Economics, 24, pp: 571-598.

Hoogeveen, J. G. (2005) Measuring welfare for small but vulnerable groups: poverty and disability in Uganda, Journal of African Economies, 14(4), pp: 603-631.

DOI: https://doi.org/10.1093/jae/eji020

JICA (2002) Country profile on disability Democratic Socialist Republic of Sri Lanka, Planning and Evaluation Department, Japan International Cooperation Agency.
Jones, A. and O'Donnell, O. (1995) Equivalence scales and the costs of disability, Journal of Public Economics, 56, pp: 273-289.

DOI: https://doi.org/10.1016/0047-2727(93)01416-8

Kakwani, N. (1993) Statistical inference in the measurement of poverty, The Review of Economics and statistics, 75, pp: 632639.

DOI: https://doi.org/10.2307/2110016

Kumara, T. (2011) Regional poverty in Sri Lanka: a multidimensional approach, Unpublished M.Econ. thesis, Graduate School of International Cooperation Studies, Kobe University, Japan.

Kumara, T. (2013) Analysing multidimensional poverty in Sri Lanka: a new measuring approach, paper presented at the $\mathrm{PhD}$. Workshop 1 at Graduate School of International Cooperation Studies, Kobe University of Japan.

Kumara, T. and Gunewardena, D. (2010) Spatial inequality in Sri Lanka, In Kelegama, S. and Gunewardena, D. (eds.) Economic and social development under a market economy regime in Sri Lanka, pp: 115-138, Colombo: Vijitha Yapa Publishers.

Maulik, P. K. and Damstadt G. L. (2007) Childhood disabilities in low and middle income countries: overview of screening, prevention, services, legislation and epidemiology, Pediatrics, 120, pp: $1-55$.

DOI: https://doi.org/10.1542/peds.2007-0043B

Mendis, P. (2004) Training and Employment of People with Disabilities: Sri Lanka 2003, Bangkok: International Labour Office.

Mete, C. (ed.) (2008) Economic implications of chronic illness and disability in Eastern Europe and the Former Soviet Union, Washington, DC: World Bank.

Meyer, B. D. and Mok, W. K. C. (2008) Disability, earnings, income and consumption. Working Paper, No. 06.10, Harris School of Public Policy Studies, University of Chicago.

Mitra, S., Findley, P. and Sambamoorthi, U. (2009) Healthcare expenditures of living with a disability: total expenditures, out of pocket expenses and burden, 1996-2004. Archives of Physical Medicine and Rehabilitation, 90, pp: 1532-1540.

DOI: https://doi.org/10.1016/j.apmr.2009.02.020

Mitra, S., Posarac, A. and Vick, B. (2013) Disability and poverty in developing countries: a multidimensional study, World Development, 41, pp: 1-18.

DOI: https://doi.org/10.1016/j.worlddev.2012.05.024

Mont, D. and Viet Cuong, N. (2011) Disability and poverty in Vietnam. World Bank Economic Review, 25(2), pp: 323-359.

DOI: https://doi.org/10.1093/wber/lhr019 
Organisation for Economic Co-operation and Development (OECD) (2009) Sickness, disability and work: keeping on track in the economic downturn, Paris: Organisation for Economic Co-operation and Development

Oxford Health Alliance (2005) Economic consequences of chronic disease and economic rationale for public and private intervention, Oxford: Oxford Health Alliance.

Palmer, M., Thuy, N., Quyen, Q., Duy, D., Huynh, H. and Berry, H. (2012) Disability measures as an indicator of poverty: a case study from Viet Nam, Journal of International Development, 24, pp: 53-68.

DOI: https://doi.org/10.1002/jid.1715

Parodi, G. and Sciulli, D. (2008) Disability in Italian households: income, poverty and labour market participation, Applied Economics, 40(20), pp: 2615-2630.

DOI: https://doi.org/10.1080/00036840600970211

Rischewski, D., Kuper, H., Atijosan, O., Simms, V., JofretBonet, M., Foster, A. and Lavy, C. (2008) Poverty and musculoskeletal impairment in Rwanda, Transactions of the Royal Society of Tropical Medicine and Hygiene, 102, pp: 608-617.

DOI: https://doi.org/10.1016/j.trstmh.2008.02.023

Saunders, P. (2007) The costs of disability and the incidence of poverty, Australian Journal of Social Issues, 42(4), pp: 461480.

DOI: https://doi.org/10.1002/j.1839-4655.2007.tb00072.x

Schultz, T. P. and Tansel, A. (1997) Wage and labour supply effects of illness in Cote d'ivoire and Ghana: Instrumental Variable Estimates for Days Disabled, Journal of Development Economics, 53, pp: 251-286.

DOI: https://doi.org/10.1016/S0304-3878(97)00025-4

Sen, A. K. (1996) On the foundations of welfare economics: utility, capability and practical reason, In Farina, F., Hahn, F. and Vannucci, S. (eds.) Ethics, rationality, and economic behaviour, Clarendon Press, pp: 50-65.

Sen, A. K. (1979) Issues in the measurement of poverty, Scandinavian Journal of Economics, 81, pp: 285-307.

DOI: https://doi.org/10.2307/3439966

Sen, A. K. (1976) Poverty: an ordinal approach to measurement, Econometrica, 44, pp: 219-231.

DOI: https://doi.org/10.2307/1912718

Sen, A. K. (2009) The idea of justice, The Belknap Press of Harvard University Press.

Sri Lanka, Central Bank of Sri Lanka (2013) Annual Report 2012, Colombo: Central Bank of Sri Lanka.
Sri Lanka, Department of Census and Statistics (DCS) (no date), Brief analysis of characteristics of the disabled persons [Online] Available from: http://www.statistics.gov.lk/ PopHouSat/PDF/p8\%20Disabled\%20Chapter.pdf [Accessed: $20^{\text {th }}$ July 2013]

Sri Lanka, Department of Census and Statistics (DCS) (2008) Final Report of the Household Income and Expenditure Survey 2006/07, Colombo: Department of Census and Statistics.

Sri Lanka, Department of Census and Statistics (DCS) (2011) Final Report of the Household Income and Expenditure Survey 2009/10, Colombo: Department of Census and Statistics.

Sri Lanka, Department of Census and Statistics (DCS) (2003) Final Report of the Household Income and Expenditure Survey 2002, Colombo: Department of Census and Statistics.

Stevens, P. (2004) Diseases of poverty and the 10/90 gap, London: International Policy Network.

Trani, J. and Loeb, M. (2012) Poverty and disability: a vicious circle? Evidence from Afghanistan and Zambia, Journal of International Development, 24, pp: 19-52.

DOI: https://doi.org/10.1002/jid.1709

United Nations Development Programme (UNDP) (2014) Human Development Report 2014: Sustaining Development Progress, New York: United Nations Development Programme.

United Nations Development Programme (UNDP) (2010) Human Development Report 2010: The real wealth of nations: Pathways to human development, New York: United Nations Development Programme.

United Nations Educational, Scientific and Cultural Organization (UNESCO) (2003) Education for all global monitoring report: the leap to equality, Paris: United Nations Educational, Scientific and Cultural Organization.

United Nations Educational, Scientific and Cultural Organization (UNESCO) (2002) Education for all global monitoring report: Is the world on track?, Paris: United Nations Educational, Scientific and Cultural Organization.

Van Agt, H. M. E., Stronks, K. and Mackenbach, J. P. (2000) Chronic illness and poverty in The Netherlands, European Journal of Public Health, 10, pp: 197-200.

DOI: https://doi.org/10.1093/eurpub/10.3.197

Vingard, E., Alexanderson, K. and Norlund, A. (2004) Consequences of being on sick leave, Scandinavian Journal of Public Health, 63, pp: 207-215.

DOI: https://doi.org/10.1080/14034950410021899

Wedgwood, R. (2007) Education and poverty reduction in Tanzania, International Journal of Educational Development, 27 (4), pp: 383-396.

DOI: https://doi.org/10.1016/j.ijedudev.2006.10.005 
WHO and World Bank (2011) World Report on Disability, World Health Organization and The World Bank.

World Bank (2009) People with disabilities in India: from commitments to outcomes, Washington, DC: World Bank.

World Bank. (2007) Sri Lanka poverty assessment: engendering growth with equity, opportunities and challenges, Washington, DC: World Bank.
Yeo, R. and Moore, K. (2003) Including disabled people in poverty reduction work: "nothing about us, without us". World Development, 31(3), pp: 571-590.

DOI: https://doi.org/10.1016/S0305-750X(02)00218-8

Zaidi, A. and Burchardt, T. (2005) Comparing incomes when needs differ: equalization for the extra costs of disability in the U.K., Review of Income and Wealth, 51, pp: 89-114.

DOI: https://doi.org/10.1111/j.1475-4991.2005.00146.x

\section{APPENDIX}

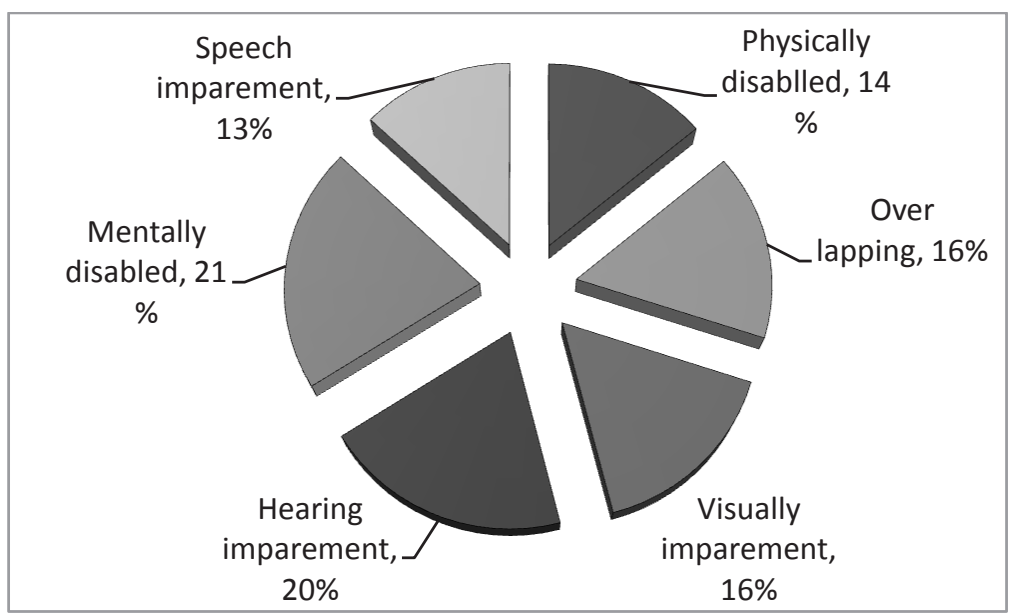

Figure I: Types of Disabilities

Source: JICA, 2002 
Table I: Variable Summaries

\begin{tabular}{|c|c|c|c|c|c|c|c|c|}
\hline \multirow[b]{2}{*}{ Level of Education } & \multicolumn{3}{|c|}{$2006 / 07$} & \multirow[b]{2}{*}{ National } & \multicolumn{4}{|c|}{$2009 / 10$} \\
\hline & Urban & Rural & Estate & & Urban & Rural & Estate & National \\
\hline No Schooling & 0.39 & 0.89 & 4.82 & 1.13 & 0.23 & 0.77 & 3.05 & 0.82 \\
\hline Some Primary & 3.71 & 4.32 & 22.65 & 7.07 & 3.96 & 5.32 & 21.39 & 6.36 \\
\hline Some Junior Secon. & 35.67 & 44.20 & 57.73 & 43.33 & 35.09 & 44.55 & 58.01 & 43.44 \\
\hline Ordinary Level $(\mathrm{O} / \mathrm{L})$ & 26.85 & 24.27 & 8.42 & 23.44 & 25.49 & 24.33 & 10.26 & 23.42 \\
\hline Advanced Level (A/L) & 25.17 & 19.91 & 5.46 & 19.88 & 25.98 & 19.49 & 5.71 & 20.0 \\
\hline Graduate & 8.22 & 4.86 & 0.93 & 5.35 & 8.43 & 50.55 & 1.5 & 5.95 \\
\hline \multicolumn{9}{|l|}{ Lighting Source } \\
\hline Kerosene & 6.11 & 19.07 & 42.80 & 18.03 & 4.80 & 13.78 & 27.59 & 12.61 \\
\hline Electricity & 93.63 & 78.60 & 55.87 & 80.25 & 95.18 & 84.11 & 71.43 & 85.93 \\
\hline Solar Power & 0.17 & 2.25 & 1.28 & 3.04 & 0.02 & 2.11 & 0.98 & 1.46 \\
\hline \multicolumn{9}{|l|}{ Drinking Water } \\
\hline Protected Well & 18.90 & 55.04 & 20.79 & 42.09 & 16.53 & 53.16 & 29.23 & 41.4 \\
\hline Unprotected Well & 0.63 & 6.46 & 7.43 & 5.09 & 0.70 & 3.96 & 50.65 & 3.24 \\
\hline Tube Well & 3.52 & 4.36 & 2.15 & 3.95 & 3.17 & 3.80 & 1.96 & 3.47 \\
\hline Pipe born & 77.20 & 26.82 & 26.71 & 39.40 & 78.15 & 36.83 & 57.02 & 49.51 \\
\hline Stream/river/tank & 0.60 & 5.03 & 38.10 & 6.99 & 0.21 & 0.84 & 3.34 & 0.89 \\
\hline Other & 2.12 & 2.29 & 4.82 & 2.48 & 1.23 & 1.41 & 2.82 & 11.49 \\
\hline \multicolumn{9}{|l|}{ Toilet Availability/Type } \\
\hline No toilet & 4.04 & 3.63 & 8.19 & 4.16 & 1.16 & 2.81 & 4.32 & 2.51 \\
\hline Shared with others & 9.67 & 6.09 & 23.87 & 8.63 & 10.91 & 6.54 & 22.41 & 9.07 \\
\hline Exclusively for family & 86.29 & 90.28 & 67.94 & 87.71 & 87.94 & 90.65 & 73.27 & 88.42 \\
\hline Water sealed & 95.70 & 93.53 & 95.70 & 95.70 & 97.68 & 96.22 & 94.32 & 96.45 \\
\hline Pit type & 4.16 & 6.33 & 4.30 & 5.60 & 2.25 & 3.74 & 5.38 & 3.48 \\
\hline \multicolumn{9}{|l|}{ Floor Type } \\
\hline Cement & 84.78 & 80.79 & 76.54 & 81.51 & 82.00 & 80.21 & 82.03 & 80.84 \\
\hline Terrazzo/tiles & 12.09 & 5.63 & 0.52 & 6.77 & 15.19 & 7.85 & 0.80 & 9.18 \\
\hline Mud & 1.53 & 11.21 & 22.18 & 9.81 & 1.56 & 8.79 & 16.30 & 7.53 \\
\hline \multicolumn{9}{|l|}{ Type of Cooking Fuel } \\
\hline Firewood & 44.77 & 84.57 & 96.97 & 75.78 & 48.23 & 85.66 & 96.83 & 76.75 \\
\hline Gas & 43.15 & 13.07 & 1.63 & 19.52 & 40.24 & 12.06 & 1.79 & 18.61 \\
\hline Kerosene & 10.89 & 1.48 & 0.17 & 3.71 & 10.13 & 1.18 & 0.29 & 3.47 \\
\hline Electricity & 0.30 & 0.12 & 0.52 & 0.20 & 0.38 & 0.20 & 0.63 & 0.29 \\
\hline Sawdust/paddy husk & 0.19 & 0.26 & 0.00 & 0.22 & 0.32 & 0.19 & 0.46 & 0.21 \\
\hline \multicolumn{9}{|l|}{ Assets Ownership } \\
\hline Radio & 79.41 & 79.33 & 71.72 & 78.64 & 73.25 & 74.60 & 68.15 & 73.68 \\
\hline Television & 81.11 & 75.14 & 60.00 & 75.23 & 84.41 & 78.31 & 66.01 & 78.85 \\
\hline Land phone & 42.46 & 29.14 & 9.06 & 30.60 & 49.31 & 45.47 & 33.81 & 45.47 \\
\hline Mobile phone & 44.18 & 28.24 & 12.60 & 30.77 & 71.83 & 58.70 & 38.71 & 60.43 \\
\hline Bicycle & 43.51 & 46.57 & 13.24 & 42.71 & 42.22 & 45.01 & 12.56 & 41.45 \\
\hline Motorcycle & 18.80 & 21.22 & 5.28 & 19.13 & 23.90 & 26.74 & 7.09 & 24.28 \\
\hline \multicolumn{9}{|l|}{ Health status } \\
\hline Chronically ill & 13.45 & 12.37 & 13.70 & 12.76 & 14.64 & 12.62 & 14.34 & 13.30 \\
\hline Hospitalized & 9.33 & 11.04 & 10.10 & 10.50 & 10.39 & 9.15 & 10.83 & 11.06 \\
\hline
\end{tabular}

Source: Authors' calculation using HIES 2006/07 and 2009/10 